\title{
A De Quervain-féle tendinopathia kezelése konzervatív módszerekkel
}

\author{
Földvári-Nagy László dr. ${ }^{1}$. Takács Johanna² \\ Hetthéssy Judit Réka dr. ${ }^{3}$ - Mayer Ágnes Andrea dr. ${ }^{4}$ \\ Szakács Noémi dr. ${ }^{3}$ - Szávin-Pósa Ágnes eh. ${ }^{2}$ - Lenti Katalin dr. ${ }^{1}$
}

\author{
'Semmelweis Egyetem, Egészségtudományi Kar, Alapozó Egészségtudományi Intézet, \\ Morfológiai és Fiziológiai Tanszék, Budapest \\ ${ }^{2}$ Semmelweis Egyetem, Egészségtudományi Kar, Budapest \\ ${ }^{3}$ Semmelweis Egyetem, Általános Orvostudományi Kar, Ortopédiai Klinika, Budapest \\ ${ }^{4}$ Semmelweis Egyetem, Egészségtudományi Kar, Alkalmazott Egészségtudományi Intézet, \\ Fizioterápiai Tanszék, Budapest
}

\begin{abstract}
Bevezetés: A De Quervain-féle tendinopathia a csukló-kéz régióját érintő betegség. A hüvelykujj mozgatása fájdalmassá válik, a kéz funkciója jelentősen romlik. A betegség a legújabb kutatások szerint inkább degeneratív, semmint gyulladásos eredetú. Első lépésként a kéz sínezése, nemszteroid gyulladáscsökkentő szerek és különböző fizikoterápiás kezelések alkalmazása javasolt. Hatástalanságuk esetén további lehetőség az ínhüvelybe fecskendezett szteroidinjekció és a mútéti úton végzett ínhüvelybemetszés.

Célkitüzés: Kutatásunkban megvizsgáltuk, hogy az excentrikus tréninggel kibővített konzervatív kezelés megfelelő alternatíváját nyújthatja-e a jelenleg elfogadott kezelési lehetőségeknek.

Módszer: Az excentrikus tréning 8 hétig tartott, melyet indokolt esetben 12 hetesre bővítettünk. A betegek $(\mathrm{n}=9)$ a betanítást követően naponta többször végezték a tréninget, amit a heti találkozók alkalmával kontrolláltunk. Az 1 ., a 8., valamint a 12. heti találkozó során az inspekciót követően mértük az ízületi mozgástartományt, az izomerőt, a fájdalmas régiók számát, illetve elvégeztük a 'Numeric Pain Rating Scale', a 'Quick Disabilities of the Arm, Shoulder and Hand', valamint a 'Patient-Rated Wrist Evaluation' kérdőívek felvételét. A méréseket páros mintás t-teszttel és ismételt méréses varianciaanalízissel elemeztük. Az elemzéseket IBM SPSS Statistics 25.0 és Microsoft Office Excel Professional Plus 2016 programmal végeztük; p<0,05 esetén tekintettük statisztikailag szignifikánsnak eredményeinket.

Eredmények: Szignifikáns javulást mértünk a fájdalom intenzitása ('Numeric Pain Rating Scale' p =0,005, n =9) és a kéz, valamint a csukló funkciója terén ('Quick Disabilities of the Arm, Shoulder and Hand Outcome Measure' kérdőív 1. rész $\mathrm{p}<0,001,2$. rész $\mathrm{p}<0,001$, 'Patient-Rated Wrist Evaluation' kérdóív $\mathrm{p}<0,001 ; \mathrm{n}=9$ ).

Következtetés: Eredményeink alapján megfelelő betegbeválasztás mellett az excentrikus tréninggel kibővített konzervatív kezelés valós alternatívája lehet a jelenleg alkalmazott kezeléseknek.

Orv Hetil. 2020; 161(11): 419-424.
\end{abstract}

Kulcsszavak: De Quervain-betegség, sztenotizáló tenosynovitis, ínhüvelyszúkület, sztenotizáló tendovaginitis, fizioterápia, fizioterápiás modalitások

\section{Treatment of De Quervain's tendinopathy with conservative methods}

Introduction: De Quervain's tendinopathy affects the region of the wrist and the hand. Thumb motion becomes painful. This illness is caused by a degenerative process rather than inflammation. Primary treatment methods are splinting, taking non-steroid anti-inflammatory drugs and different physical therapeutic modalities, administration of a steroid injection into the tendon sheath or surgical release of the tendon sheath may be performed.

Aim: The aim of the present study was to investigate whether conservative treatment complemented by eccentric training could provide an adequate alternative to the currently accepted treatment options.

Method: The eccentric training lasted for 8 weeks (if necessary for 12 weeks). Following the introduction to exercises, patients $(n=9)$ repeated the training several times a day, which was controlled during weekly meetings. At the lst, 8th and 12th meetings, inspection and the following measurements were performed: range of motion, muscle strength, evaluation and number of painful regions including the completion of patient questionnaires. Data were 
analysed with paired samples t-tests and repeated measures ANOVA. IBM SPSS Statistics 25.0 and Microsoft Office Excel Professional Plus 2016 programs were used. Results were regarded significant at level of $\mathrm{p}<0.05$.

Results: Significant improvements were found in the intensity of pain (Numeric Pain Rating Scale $\mathrm{p}=0.005, \mathrm{n}=9$ ) and in the functionality of the hand and wrist (Quick Disabilities of the Arm, Shoulder and Hand questionnaire part 1. $\mathrm{p}<0.001$, part 2. $\mathrm{p}<0.001$, Patient-Rated Wrist Evaluation questionnaire $\mathrm{p}<0.001 ; \mathrm{n}=9$ ).

Conclusion: With careful patient selection, conservative treatment complemented by eccentric training could be an alternative to current treatment options.

Keywords: De Quervain's disease, stenosing tenosynovitis, tendon entrapment, stenosing tendovaginitis, physiotherapy (techniques), physical therapy modalities

Földvári-Nagy L, Takács J, Hetthéssy JR, Mayer ÁA, Szakács N, Szávin-Pósa Á, Lenti K. [Treatment of De Quervain’s tendinopathy with conservative methods]. Orv Hetil. 2020; 161(11): 419-424.

(Beérkezett: 2019. október 21.; elfogadva: 2019. november 20.)

\begin{abstract}
Rövidítések
ANOVA $=$ (analysis of variance $)$ varianciaanalízis; EÜIG $=a z$ Emberi Erőforrások Minisztériuma Országos Tisztifőorvosi Feladatokért Felelős Helyettes Államtitkárságának Egészségügyi Igazgatási Főosztálya; m. = musculus; NPRS = $($ Numeric Pain Rating Scale) a legerősebb fájdalom mértékét mérő kérdő́v; PRWE = (Patient-Rated Wrist Evaluation $)$ a kéz funkcióbetöltő képességét és a fájdalom mértékét mérő kérdőív; $\mathrm{SD}=$ standard deviáció; QuickDASH = (Quick Disabilities of the Arm, Shoulder and Hand) a kéz funkcióbetöltő képességét mérő kérdőív
\end{abstract}

Johann Friedrich de Quervain 1895-ben írta le először a róla elnevezett De Quervain-féle tendinopathiát [1]. A betegség a csukló-kéz radiális régióját, pontosabban az I. dorsalis extensor rekeszt, valamint a benne futó musculus abductor pollicis longust és a m. extensor pollicis brevist érinti [1]. Hónapok alatt fokozatosan fájdalmassá válik az érintett oldali hüvelykujj extensiója és/vagy abductiója [2-4], fájdalom jelentkezik a fossa Tabatiere és a processus styloideus radii környékén $[5,6]$, a kéz csavaró, emelő, markoló mozdulatai nehezítetté, egyes esetekben kivitelezhetetlenné válhatnak [5]. Az érintett terület duzzadttá [2-4], tapintásra érzékennyé válhat [2-4], a mozgásokat kísérheti ropogó hang [7] vagy pattanásérzet [7]. A gyulladásra utaló tünetek előfordulása tekintetében nem egységes az irodalom [3, 8-10].

A betegség szövettani képét kutatva mára úgy vélik, inkább a degeneratív elváltozások adják a probléma hátterét, semmint a gyulladás [8], ami a kezelési módszerekre is befolyással bír. Jelenleg első lépésként konzervatív kezelési módszerek alkalmazandók, hatástalanságuk esetén a mútéti úton végzett ínhüvelybemetszés indikált [11]. A nemzetközi szakirodalom emellett az ínhüvelybe fecskendezett szteroidinjekciót is ajánlja [9].

A De Quervain-féle tendinopathia kezelésére a gyakorlatban többféle konzervatív terápiát alkalmaznak. A rögzítés hatásosságáról eltérő eredményeket olvashatunk $[12,13]$ - bevezetô terápiaként, enyhe esetekben érdemes alkalmazni [14]. A sínezést önmagában nem tartják hatékony kezelési módszernek $[15,16]$, nemszteroid gyulladáscsökkentőkkel kombinálva azonban hatékony lehet [17]. A különböző nemszteroid gyulladáscsökkentő szerek alkalmazása széles körben bevett kezelési mód [14], ám önálló hatékonyságukat nehéz megítélni, mivel gyakran kombinálják óket más konzervatív eljárásokkal $[17,18]$. A fizioterápiás eljárások (termoterápia, diatermia, masszázs) hatásossága nem bizonyított [13], kutatják hatékonyságukat [19]. Megtalálható a kezelési javaslatok között a korai mobilizáció, a diatermiás kezelés, a haránt irányú dörzsmasszázs stb. $[13,20,21]$, de ezen eljárások hatásosságát még nem igazolták [13].

A betegség hisztopatológiája arra enged következtetni, hogy olyan konzervatív eljárások is megfontolhatók, amelyek a degeneratív elváltozásra jótékony hatással vannak, mint például a gyógytornászok által alkalmazott excentrikus tréning. Ennek pontos hatásmechanizmusa még nincs teljesen tisztázva, de számos elképzelés született a tréning lehetséges hatásmechanizmusáról [10].

Kutatócsoportunk a De Quervain-féle tendinopathia konzervatív kezelési lehetőségei közül az excentrikus tréning hatásosságának vizsgálatát tûzte ki célul. Választ kerestünk arra, hogy:

- az excentrikus tréninggel kibővített konzervatív kezelés képes-e a csukló-kéz régióban tapasztalt fájdalmat csökkenteni és a kéz funkcióját javítani,

- elegendő-e az excentrikus tréning 8 hétig történő alkalmazása,

- az excentrikus tréninggel kibővített konzervatív kezelés hatásossága megközelíti-e a szteroidinjekcióét és a mútéti ínhüvelybemetszését.

\section{Módszer}

A vizsgálatba 13 beteget vontunk be; 4 fó a program vége előtt kizárásra került a program elhagyása miatt. A betegség kialakulásának oka változatos volt, és nem minden esetben lehetett a lehetséges kiváltó okot felderíteni. Öt fó lépett a kutatást megelőzően kapcsolatba a 
kutatócsoportunkon kívüli más orvossal. A korábban előírt kezelések általában a kéz sínezése, nemszteroid gyulladáscsökkentő és fájdalomcsillapító gyógyszerek szedése, valamint antiphlogistin krém használata volt. Emellett kettejüknél 10 alkalmas fizikoterápiás kezelést írtak elő (iontoforézis, hidrogalván-kezelés). 1 fó kapott nemszteroid gyulladáscsökkentő injekciót az érintett ínhüvelybe. Valamennyi beteg a panaszok enyhülését tapasztalta a fenti kezelések hatására, de nem következett be tartós javulás, sőt néhányuknál idővel visszaesés történt. A kutatásba vont személyek panaszai átlagosan 6-7 hónapja álltak fenn (legrövidebb: 1 hónap, leghosszabb: másfél év), legalább egyszer átestek sikertelen konzervatív kezelésen, és nem volt várható mútéti ellátás.

A betegek egy részénél sín használata és/vagy nemszteroid gyulladáscsökkentő szerek orális, illetve lokális használata, valamint egyes esetekben fizikoterápiás kezelések kerültek elö́rásra.

Beválasztásra került betegeink a fenti kezeléseket kiegészítve részt vettek egy 8 , illetve szükség esetén 12 hetes excentrikus tréningprogramon.

A tréningprogramot a betanítást követően napi rendszerességgel, de legalább heti ötször, az irodalmi adatoknak megfelelő ismétlésszámmal [22] kellett, hogy végezzék a betegek, amit a heti találkozók alkalmával kontrolláltunk. Azok a betegek, akik nem végezték megfelelő rendszerességgel a gyakorlatokat, 12 hétig kapták a kezelést $(\mathrm{n}=4)$.

Az 1. és a 8 . heti, valamint a 12 . heti találkozó során az inspekciót követően felmérésre került az ízületi mozgástartomány, az izomerő, a fájdalmas régiók száma, valamint felvételre kerültek az alábbi kérdő́ívek: 'Numeric Pain Rating Scale' (a továbbiakban: NPRS [23]), 'Quick Disabilities of the Arm, Shoulder and Hand Outcome Measure' (a továbbiakban: QuickDASH [24]), 'PatientRated Wrist Evaluation' (a továbbiakban: PRWE [25]). A fájdalmas régiók számának meghatározásához három képet mutattunk a betegeknek: ezeken a kézhát felől, oldalról a hüvelykujj felől és a tenyér felől láthattak egy olyan kezet, melyet előzetesen 14 régióra osztottunk fel. A hüvelykujjat és közvetlen környékét 14 régióra osztottuk (az alsó felszínen 5 , a felső felszínen 5 és az oldalsó felszínen 4 darabra). Arra kértük a betegeket, hogy jelöljék meg a mutatott képen behatárolt régiók közül, hányban éreznek fájdalmat. Az 1-8. heti adatokat páros mintás t-teszttel értékeltük ki. Ismételt méréses varianciaanalízist alkalmaztunk a 12 hetes tréningprogram esetén. Az elemzéseket IBM SPSS Statistics 25.0 (IBM

1. táblázat |Az NPRS a kezelést megelőzően (1. hét) és a 8. hét után $(\mathrm{n}=9)$

\begin{tabular}{c|c|c|c|c|c|c|c}
\hline \multicolumn{3}{c|}{ 1. hét } & \multicolumn{3}{c|}{ 8. hét } & \multirow{2}{*}{$\mathrm{t}$} & $\mathrm{p}$ \\
\cline { 1 - 6 } $\mathrm{M}$ & SD & SE & $\mathrm{M}$ & SD & SE & & \\
\hline 8,00 & 1,23 & 0,41 & 3,22 & 3,49 & 1,16 & 3,873 & 0,005 \\
\hline
\end{tabular}

NPRS = Numeric Pain Rating Scale
Corporation, Armonk, NY, Amerikai Egyesült Államok [USA]) és Microsoft Office Excel Professional Plus 2016 programmal (Microsoft Corporation, Redmond, WA, USA) végeztük; $p<0,05$ esetén tekintettük szignifikánsnak az eredményeket.

\section{Eredmények}

A résztvevők legjellemzőbb tünetei a kiindulás során a fájdalom $(\mathrm{n}=8 ; 88,9 \%)$, az érzékenység $(\mathrm{n}=7 ; 77,8 \%)$, a mozgásbeszúkülés $(\mathrm{n}=4 ; 44,4 \%)$, a duzzanat $(\mathrm{n}=4$; $44,4 \%)$, a pattanásérzet $(\mathrm{n}=3 ; 33,3 \%)$, a ropogó hang $(\mathrm{n}=2 ; 22,2 \%)$ és a feszülő, húzódó érzés $(\mathrm{n}=2 ; 22,2 \%)$ volt.

Az érintett terület a processus styloideus radii környéke volt, de a fájdalom a legtöbb esetben változó mértékben kiterjedt a kézhát irányába, az alkarra a csuklótól 3-5 $\mathrm{cm}$-ig és a hüvelykujj distalis vége felé. A legerősebb fájdalmat a résztvevők átlagosan 10-ból 8-as $(\mathrm{SD}=1,23)$ erősségüre becsülték. A napközben sokszor megjelenő sajgásról csak 4 fő számolt be, de ők egységesen 3-ra értékelték az erősségét. Éjszaka, illetve a kéz használatának teljes mellőzésekor senki nem érzett fájdalmat.

A legerősebb fájdalomnak a 8 . hétre történő 4,78 pontos $(59,8 \%)$ csökkenése szignifikáns $(\mathrm{p}=0,005)$, ami az NPRS esetén (mivel meghaladja a 2 pontot vagy a 30,0\%-ot) klinikailag már jelentős változásnak számít (1. táblázat).

A kéz funkciója tekintetében mind a hétköznapi feladatok ellátásában $(\mathrm{n}=9)$, mind a munkával kapcsolatos választható modul esetén $(\mathrm{n}=8)$ szignifikáns változást értünk el. A hétköznapi funkciók esetén 34,88 pontos, tehát 74,8\%-os $(\mathrm{p}<0,001)$, míg a munkával kapcsolatos modul esetében 38,28 pontos, tehát $84,5 \%$-os $(\mathrm{p}<0,001)$ javulást mértünk a 8 . hét végére. ( 1 beteg a terápia teljes tartama alatt betegszabadságon volt, így nem lehetett felmérni a munkával kapcsolatos részt.) A kérdőív harmadik részének (sporttal/előadó-művészettel kapcsolatos választható modul) statisztikai kiértékelése nem volt lehetséges, mivel a betegek közül csak 1 fó sportolt a kezelés előtt, alatt és után is, a többi betegnél vagy hiányzott valamelyik érték, vagy nem sportoltak egyáltalán (2. táblázat).

Tekintve, hogy nincs arra vonatkozó utasítás a szakirodalomban, hogy hány válasz hiánya esetén értékelhető még ki a kérdőív [26], l hiányosan kitöltött kérdőívet ki kellett zárnunk. 8 beteg adatai alapján a mért átlagok 46,69-ról 13,53 pontra csökkentek a 8 . hét végére $(\mathrm{p}<0,001)$, azaz a javulás 33,16 pont $(71,0 \%)$ volt. A kapott 13,53 pontos átlag jobban megközelíti a 7,7-es normálátlagot [26] (3. táblázat).

A fájdalmas régiók számának tekintetében klinikailag jelentôs változásról számolhatunk be. Az 1 . hét (56 régió; $M=3,00, S D=2,74$ ) és a 8 . hét ( 12 régió; $M=$ $1,00, S D=0,84)$ között 44 régióban szûnt meg a fájdalom együttesen, ami 78,6\%-os javulást jelent. 
2. táblázat |A kéz funkcióbetöltő képessége (QuickDASH: 1. rész $-\mathrm{n}=9,2$. rész $-\mathrm{n}=8$ ) a kezelést megelőzően (1. hét) és a 8 . hét után

\begin{tabular}{|c|c|c|c|c|c|c|c|c|}
\hline \multirow{3}{*}{$\begin{array}{l}\text { QuickDASH kérdốív l. rész* } \\
(\mathrm{n}=9)\end{array}$} & \multicolumn{3}{|c|}{ 1. hét } & \multicolumn{3}{|c|}{8 . hét } & \multirow[t]{2}{*}{$\mathrm{t}$} & \multirow[t]{2}{*}{$\mathrm{p}$} \\
\hline & M & SD & SE & M & SD & SE & & \\
\hline & 46,62 & 14,00 & 4,67 & 11,74 & 10,72 & 3,57 & 5,833 & $<0,001$ \\
\hline \multirow{3}{*}{$\begin{array}{l}\text { QuickDASH kérdoóív 2. rész** } \\
(\mathrm{n}=8)\end{array}$} & \multicolumn{3}{|c|}{ 1. hét } & \multicolumn{3}{|c|}{8 . hét } & \multirow[t]{2}{*}{$\mathrm{t}$} & \multirow[t]{2}{*}{$\mathrm{p}$} \\
\hline & M & SD & SE & $M$ & SD & SE & & \\
\hline & 45,31 & 17,28 & 6,10 & 7,03 & 9,11 & 3,22 & 6,187 & $<0,001$ \\
\hline
\end{tabular}

* 1. rész a hétköznapi funkciókra vonatkozik.

**2. rész a munkával kapcsolatos modul.

QuickDASH = Quick Disabilities of the Arm, Shoulder and Hand

3. táblázat $\mid$ A kéz funkcióbetöltő képessége és a fájdalom mértéke (PRWE) a kezelést megelőzően (1. hét) és a 8 . hét után $(\mathrm{n}=8)$

\begin{tabular}{c|c|c|c|c|c|c|c}
\hline \multicolumn{3}{c|}{ 1. hét } & \multicolumn{3}{c|}{ 8. hét } & \multirow{2}{*}{$\mathrm{N}$} & $\mathrm{p}$ \\
\cline { 1 - 6 } M & SD & SE & M & SD & SE & & \\
\hline 46,69 & 11,08 & 3,92 & 13,53 & 11,38 & 4,02 & 7,257 & $<0,001$ \\
\hline
\end{tabular}

PRWE $=$ Patient-Rated Wrist Evaluation

4. táblázat |A legerősebb fájdalom mértéke (NPRS) a kezelést megelőzően (1. hét), a 8 . és a 12 . hét után $(n=4)$

\begin{tabular}{c|c|c|c|c|c|c|c}
\hline \multicolumn{2}{c|}{ 1. hét } & \multicolumn{2}{c|}{ 8. hét } & \multicolumn{2}{c|}{ 12. hét } & \multirow{2}{*}{$\mathrm{F}$} & \multirow{2}{*}{$\mathrm{p}$} \\
\cline { 1 - 6 } $\mathrm{M}$ & $\mathrm{SD}$ & $\mathrm{M}$ & $\mathrm{SD}$ & $\mathrm{M}$ & $\mathrm{SD}$ & & \\
\hline 8,75 & 1,50 & 3,75 & 3,50 & 2,00 & 4,00 & 9,872 & 0,013 \\
\hline
\end{tabular}

NPRS = Numeric Pain Rating Scale

Azon betegek esetében, akik nem végezték az előírt rendszerességgel és ismétlésszámmal a gyakorlatokat, és emiatt a gyógyulás nem következett be a 8 . hétig, a terápiát kibővítettük 12 hetesre $(n=4)$. Náluk is szignifikáns javulást mértünk a legerősebb fájdalom területén $(\mathrm{p}=$ $0,013)$. Az l. heti 8,75-ös átlag a 8. hétre 3,75-re csökkent ( 5 pont különbség, $57,1 \%$-os javulás), a 12 . hétre pedig tovább csökkent 2 pontra ( 1,75 pont különbség, 46,7\%-os további javulás). A javulás mértékét tekintve az értékek meghaladták a klinikailag jelentős, 30\%-os határértéket [27] (4. táblázat).

A 4 beteg kézfunkciója a mindennapi tevékenységek során szignifikánsan javult a QuickDASH kérdőív 1. részének kitöltése alapján $(\mathrm{p}<0,001)$. Az 1 . héten 52,05 átlagos pontértéket mértünk, a 8 . héten 17,04-et $(35,01$ pont különbség, 67,3\%-os javulás), a 12. héten már csak 5,68 pontot jelöltek (11,36 pont különbség, 66,7\%-os további javulás). Az 1. és a 12. heti mérések között öszszegezve $89,1 \%$-os javulást mértünk (46,37 pont). A kérdőív 2. részének kitöltése során csak 3 beteg adatait elemeztük, mivel - mint a 2. táblázatnál írtuk - az egyik résztvevő a kezelés teljes időtartama alatt betegszabadságon volt, így nem tudta kitölteni a munkára vonatkoztatott választható modult. Az 1 . héten átlagosan 45,83 pontról indultak a betegek, amely a 8 . hétre 12,50 pontra csökkent (33,33 pont különbség, $72,7 \%$ javulás), a 12 . hétre pedig 0 pontot adtak a betegek (100\%-os javulás), azaz valamennyi beteg keze teljesen el tudta látni a funkcióját munkavégzés során $(\mathrm{p}=0,010)$. A kérdốiv 3. részének értelmezése a 2. táblázatnál leírtak miatt továbbra sem volt lehetséges (5. táblázat).

A 4 beteg közül 1 hiányosan töltötte ki a kérdőívet, ezért kérdőíve kizárásra került. A fennmaradt 3 beteg eredményét kiértékelve az 1 . hét 51,50 ponttal indult, a 8. héten 22,17 pontot mértünk (29,33 pont, azaz $57,0 \%$ javulás), a 12 . héten 6,67 pontot jelöltek a betegek $(15,5$ pont, $69,9 \%$ további javulás). Az l. és a 12 . hét között

5. táblázat |A kéz funkcióbetöltő képessége (QuickDASH: 1. rész $-\mathrm{n}=4,2$. rész $-\mathrm{n}=3$ ) a kezelést megeloozóen (1. hét), a 8. és a 12. hét után

\begin{tabular}{|c|c|c|c|c|c|c|c|c|}
\hline \multirow{3}{*}{$\begin{array}{l}\text { QuickDASH kérdő́iv l. rész* } \\
(\mathrm{n}=4)\end{array}$} & \multicolumn{2}{|c|}{ 1. hét } & \multicolumn{2}{|c|}{8 . hét } & \multicolumn{2}{|c|}{ 12. hét } & \multirow[t]{2}{*}{$\mathrm{F}$} & \multirow[t]{2}{*}{$\mathrm{p}$} \\
\hline & M & SD & M & SD & M & SD & & \\
\hline & 52,05 & 10,28 & 17,04 & 9,90 & 5,68 & 3,94 & 41,214 & $<0,001$ \\
\hline \multirow{3}{*}{$\begin{array}{l}\text { QuickDASH kérdóív 2. rész** } \\
(\mathrm{n}=3)\end{array}$} & \multicolumn{2}{|c|}{ 1. hét } & \multicolumn{2}{|c|}{8 . hét } & \multicolumn{2}{|c|}{ 12. hét } & \multirow[t]{2}{*}{$\mathrm{F}$} & \multirow[t]{2}{*}{$\mathrm{p}$} \\
\hline & M & SD & M & SD & M & SD & & \\
\hline & 45,83 & 18,04 & 12,50 & 12,50 & 0,00 & 0,00 & 17,636 & $<0,010$ \\
\hline
\end{tabular}

*1. rész a hétköznapi funkciókra vonatkozik.

**2. rész a munkával kapcsolatos modul.

QuickDASH $=$ Quick Disabilities of the Arm, Shoulder and Hand 
6. táblázat A kéz funkcióbetöltő képessége és a fájdalom mértéke (PRWE) a kezelést megelőzően (1. hét), a 8 . és a 12 . hét után $(n=3)$

\begin{tabular}{c|c|c|c|c|c|c|c}
\hline \multicolumn{2}{c|}{ 1. hét } & \multicolumn{2}{c|}{ 8. hét } & \multicolumn{2}{c|}{ 12. hét } & \multirow{2}{*}{ F } & \multirow{2}{*}{$\mathrm{p}$} \\
\cline { 1 - 6 } M & SD & M & SD & M & SD & & \\
\hline 51,5 & 14,55 & 22,17 & 8,08 & 6,67 & 6,75 & 19,215 & 0,009 \\
\hline
\end{tabular}

PRWE $=$ Patient-Rated Wrist Evaluation

44,83 pont $(87,0 \%)$ javulást mértünk (6. táblázat). A 12. hétre adott 6,67 pontos átlag alacsonyabb, mint a normálátlagnak tekintett 7,7 pont [26].

A 9 beteg által összesen megjelölt fájdalmas régiók számából (56) 29-et az a 4 beteg jelölt be, akinek a tréningprogramját végül ki kellett bővíteni 12 hetesre. A javulás mértéke az 1 . hét ( 29 régió; $\mathrm{M}=4,00, \mathrm{SD}=2,77$ ) és a 8 . hét ( 5 régió; $M=1,00, S D=0,74)$ között $82,8 \%$ os volt ( 24 régió fájdalma tünt el). A következő 4 hét alatt további 1 régióval csökkent a szám, így értük el a 4 régiót a kezelés végére (12. hét: $4 ; \mathrm{M}=1,00, \mathrm{SD}=0,53)$. $\mathrm{Az}$ 1. és a 12. hét között 86,2\%-os javulást értünk el.

Külön kiemelendő, hogy azon betegek $(\mathrm{n}=4)$, akik végezték ugyan a tréninget, de nem az elóírásnak megfelelő gyakorisággal, 12 hetesre növelve a kezelés időtartamát, hasonló mértékű javulást mutattak, mint azok, akik 8 hétig az előírás szerinti gyakorisággal végezték a tréningprogramot.

\section{Megbeszélés}

Irodalmi adatok alapján a konzervatív kezelések hatékonysága eltérő. A gipszelés hatékonysága 36\% [12], a sínezés 19\% [18], a pihentetés és a nemszteroid gyulladáscsökkentő és fájdalomcsillapító szerek hatékonysága 0\% [28]. A szteroidinjekció hatékonysága 60-90\% közötti [15, 18, 28-30], azonban kevés a megfelelő alapossággal kivitelezett vizsgálat. Kevés azon vizsgálatok száma, amelyeknél placebokészítménnyel vetették össze a szteroidinjekció hatását, emiatt több tanulmány megkérdőjelezi a létjogosultságát, tekintve, hogy degeneratív, és nem gyulladásos elváltozás feltételezhető [31]. A kezelések kombinációja (szteroidinjekció és sínezés) átlagosan 57\%-ban bizonyult hatásosnak [18]. A mütéti kezelés sikeressége $90 \%$ felettire tehető $[32,33]$.

$\mathrm{Az}$ excentrikus tréning előnye, hogy régóta alkalmazzák sikerrel egyéb tendinopathiák kezelésére (például Achilles- [34], rotátorköpeny- [35], ligamentum patellae tendinopathia [36], lateralis epicondylitis [37]). Könnyen tanulható, otthon végezhető módszerről lévén szó, nincs szükség gyógyszerfelírásra, és a járóbeteg-ellátás keretein belül betanítható.

Az excentrikus tréning hatásmechanizmusa még nem teljesen tisztázott. Egyelőre még kevés a bizonyítékon alapuló ismeret, ezért kellenek a megfelelő alapossággal kivitelezett vizsgálatok [38-41].

Eredményeink arra világítanak rá, hogy a felsorolt, 0-36\% közötti hatékonysággal alkalmazható konzerva- tív, nem invazív eljárásokhoz képest az excentrikus tréninggel kibővített konzervatív kezelés a mútéti eljárással azonos, 90\% feletti hatékonyságú, de a mütéti eljárás esetleges komplikációi nélkül [42].

Megfelelő betegbeválasztás esetén az excentrikus tréning hozzájárulhat a fájdalom intenzitásának csökkenéséhez, illetve a kéz funkciójának javulásához a De Quervain-féle tendinopathia esetében, és javítható a kéz funkcióbetöltő képessége. A hatás eléréséhez vizsgálataink alapján 8 hétre van szükség, de a módszer eredményességét nagyban befolyásolja a betegek önfegyelme és a tréning rendszeres végzése. Indokolt esetben a tréningprogram 12 hetesre bővítésével lehet elősegíteni a panaszok javulását. Az excentrikus tréning megközelíti vagy akár meg is haladja a magyar protokoll szerinti kezelés eredményességét.

Munkánk pilot jellegű kutatás; az Országos Tisztiföorvosi Hivatal 408-2/2018/EÜIG számú engedélyének megfelelően nagyobb populáción is vizsgáljuk a kezelés hatékonyágát, de a rendelkezésre álló adatok alapján a De Quervain-féle tendinopathia jelenleg elfogadott kezelési módszerei mellé alternatív konzervatív eljárásként kimagasló hatásossággal javasolható az excentrikus tréning.

Anyagi támogatás: A kutatás költségeit a Semmelweis Innovációs Igazgatóság által meghirdetett és megnyert pályázatból, a Semmelweis Innovációs Díjból fedeztük.

Szerzôi munkamegosztás: F.-N. L.: Irodalomkutatás, a cikk megírása, szakmai konzulens. T. J.: A statisztikai elemzésekhez nyújtott segítséget. H. J. R.: Szakmai konzulens, orvosi szakvizsgálat. M. Á. A.: Szakmai konzulens. Sz. N.: Szakmai konzulens, orvosi szakvizsgálat. Sz.-P. Á.: Excentrikus tréning, adatrögzítés. L. K.: Kutatásvezető, szakmai irányítás és kontroll, a cikk megírása. A cikk végleges változatát valamennyi szerző elolvasta és jóváhagyta.

Érdekeltségek: A szerzőknek nincsenek érdekeltségeik.

\section{Köszönetnyilvánítás}

A szerző́k köszönetüket fejezik ki a Semmelweis Egyetem Ortopédiai Klinikájának az együttmúködésért.

\section{Irodalom}

[1] De Quervain F. On a form of chronic tendovaginitis. (Translated article: Cor.-Bl. f. schweiz. Aerzte 1895; 25: 389-394). J Hand Surg Br. 2005; 30: 388-391.

[2] Shehab R, Mirabelli MH. Evaluation and diagnosis of wrist pain: a case-based approach. Am Fam Physician 2013; 87: 568-573. [Published correction appears in Am Fam Physician 2013; 88: 427.]

[3] Piligian G, Herbert R, Hearns M, et al. Evaluation and management of chronic work-related musculoskeletal disorders of the distal upper extremity. Am J Ind Med. 2000; 37: 75-93. 
[4] Gupta AD, Mahalanabis D. Study of hand function in a group of shoe factory workers engaged in repetitive work. J Occup Rehabil. 2006; 16: 675-684.

[5] Dawson C, Mudgal CS. Staged description of the Finkelstein test. J Hand Surg Am. 2010; 35: 1513-1515.

[6] Finkelstein H. Stenosing tendovaginitis at the radial styloid process. J Bone Jt Surg. 1930; 12: 509-540.

[7] Alberton GM, High WA, Shin AY, et al. Extensor triggering in De Quervain's stenosing tenosynovitis. J Hand Surg Am. 1999; 24: 1311-1314.

[8] Clarke MT, Lyall HA, Grant JW, et al. The histopathology of De Quervain's disease. J Hand Surg Br. 1998; 23: 732-734.

[9] Huisstede BM, Hoogvliet P, Coert JH, et al. Multidisciplinary consensus guideline for managing trigger finger: results from the European HANDGUIDE Study. Phys Ther. 2014; 94: 14211433.

[10] Rees JD, Lichtwark GA, Wolman RL, et al. The mechanism for efficacy of eccentric loading in Achilles tendon injury; an in vivo study in humans. Rheumatology 2008; 47: 1493-1497.

[11] Hungarian Orthopedic Professional College. Protocol of the Ministry of Health on articular synovitis and tenosynovitis. [Ortopédiai Szakmai Kollégium. Az Egészségügyi Minisztérium szakmai protokollja: A kézízületi synovitisekről és tenosynovitisekről.] Egészségügyi Közlöny 2009; LIX: 3259-3264. [Hungarian]

[12] Mehdinasab SA, Alemohammad SA. Methylprednisolone acetate injection plus casting versus casting alone for the treatment of De Quervain's tenosynovitis. Arch Iran Med. 2010; 13: 270-274.

[13] Moore JS. De Quervain's tenosynovitis. Stenosing tenosynovitis of the first dorsal compartment. J Occup Environ Med. 1997; 39: 990-1002.

[14] Huisstede BM, Coert JH, Friden J, et al., European HANDGUIDE Group. Consensus on a multidisciplinary treatment guideline for De Quervain disease: results from the European HANDGUIDE Study. Phys Ther. 2014; 94: 1095-1110.

[15] Weiss AP, Akelman E, Tabatabai M. Treatment of De Quervain's disease. J Hand Surg Am. 1994; 19: 595-598.

[16] Avci S, Yilmaz C, Sayli U. Comparison of nonsurgical treatment measures for De Quervain's disease of pregnancy and lactation. J Hand Surg Am. 2002; 27: 322-324.

[17] Lane LB, Boretz RS, Stuchin SA. Treatment of De Quervain's disease: role of conservative management. J Hand Surg Am. 2001; 26: 258-260.

[18] Ilyas AM. Nonsurgical treatment for De Quervain's tenosynovitis. J Hand Surg Am. 2009; 34: 928-929.

[19] Backstrom MK. Mobilization with movement as an adjunct intervention in a patient with complicated De Quervain's tenosynovitis: a case report. J Orthop Sport Phys Ther. 2002; 32: $86-97$.

[20] Hadianfard M, Ashraf A, Fakheri M, et al. Efficacy of acupuncture versus local methylprednisolone acetate injection in De Quervain's tenosynovitis: a randomized controlled trial. J Acupunct Meridian Stud. 2014; 7: 115-121.

[21] Faithfull DK, Lamb DW. De Quervain's disease - a clinical review. Hand 1971; 3: 23-30.

[22] Papa JA. Conservative management of De Quervain's stenosing tenosynovitis: a case report. J Can Chiropr Assoc. 2012; 56: 112-120.

[23] Hawker GA, Mian S, Kendzerska T, et al. Measures of adult pain: Visual Analog Scale for pain (VAS Pain), Numeric Rating Scale for pain (NRS Pain), McGill Pain Questionnaire (MPQ), shortform McGill Pain Questionnaire (SF-MPQ), Chronic Pain Grade Scale (CPGS), Short form-36 Bodily Pain Scale (SF-36 BPS), and measure of Intermittent and Constant Osteoarthritis Pain (ICOAP). Arthritis Care Res. 2011; 63: 240-252.
[24] Gummesson C, Ward MM, Atroshi I. The shortened disabilities of the arm, shoulder and hand questionnaire (QuickDASH): validity and reliability based on responses within the full-length DASH. BMC Musculoskelet Disord. 2006; 7: 44.

[25] Goldhahn J, Shisha T, MacDermid JC, et al. Multilingual crosscultural adaptation of the patient-rated wrist evaluation (PRWE) into Czech, French, Hungarian, Italian, Portuguese (Brazil), Russian and Ukrainian. Arch Orthop Trauma Surg. 2013; 133: 589-593.

[26] Mulders MA, Kleipool SC, Dingemans SA, et al. Normative data for the patient-rated wrist evaluation questionnaire. J Hand Ther. 2018; 31: 287-294.

[27] Farrar JT, Young JP Jr, LaMoreaux L, et al. Clinical importance of changes in chronic pain intensity measured on an 11-point numerical pain rating scale. Pain 2001; 94: 149-158.

[28] Richie CA 3rd, Briner WW Jr. Corticosteroid injection for treatment of De Quervain's tenosynovitis: a pooled quantitative literature evaluation. J Am Board Fam Pract. 2003; 16: 102-106.

[29] Harvey FJ, Harvey PM, Horsley MW. De Quervain's disease: surgical or nonsurgical treatment. J Hand Surg Am. 1990; 15: 83-87.

[30] McAuliffe JA. Tendon disorders of the hand and wrist. J Hand Surg Am. 2010; 35: 846-853.

[31] Peters-Veluthamaningal C, van der Windt DA, Winters JC, et al. Corticosteroid injection for De Quervain's tenosynovitis. Cochrane Database Syst Rev. 2009; (3): CD005616.

[32] Azeem M, Iqbal MZ, Ahmed N, et al. Outcome of surgical treatment of De-Quervains disease. J Sheikh Zayed Med Coll. 2014; 5: 655-657.

[33] Scheller A, Schuh R, Hönle W, et al. Long-term results of surgical release of De Quervain's stenosing tenosynovitis. Int Orthop. 2009; 33: 1301-1303.

[34] Alfredson H, Pietilä T, Jonsson P, et al. Heavy-load eccentric calf muscle training for the treatment of chronic achilles tendinosis. Am J Sports Med. 1998; 26: 360-366.

[35] Dejaco B, Habets B, van Loon C, et al. Eccentric versus conventional exercise therapy in patients with rotator cuff tendinopathy: a randomized, single blinded, clinical trial. Knee Surg Sports Traumatol Arthrosc. 2017; 25: 2051-2059.

[36] Visnes H, Bahr R. The evolution of eccentric training as treatment for patellar tendinopathy (jumper's knee): a critical review of exercise programmes. Br J Sports Med. 2007; 41: 217-223.

[37] Malliaras P, Maffulli N, Garau G. Eccentric training programmes in the management of lateral elbow tendinopathy. Disabil Rehabil. 2008; 30: 1590-1596.

[38] Frizziero A, Trainito S, Oliva F, et al. The role of eccentric exercise in sport injuries rehabilitation. Br Med Bull. 2014; 110: $47-75$.

[39] Kingma JJ, De Knikker R, De Wittink HM, et al. Eccentric overload training in patients with chronic Achilles tendinopathy: a systematic review. Br J Sports Med. 2007; 41: e3.

[40] Wasielewski NJ, Kotsko KM. Does eccentric exercise reduce pain and improve strength in physically active adults with symptomatic lower extremity tendinosis? A systematic review. J Athl Train. 2007; 42: 409-421.

[41] Woodley BL, Newsham-West RJ, Baxter GD. Chronic tendinopathy: effectiveness of eccentric exercise. Br J Sports Med. 2007; 41: 188-198.

[42] Abrisham SJ, Karbasi MH, Zare J, et al. De Qeurvian tenosynovitis: clinical outcomes of surgical treatment with longitudinal and transverse incision. Oman Med J. 2011; 26: 91-93.

(Földvári-Nagy László dr., Budapest, Vas u. 17., 1088 e-mail: foldvari.nagy.laszlo@se-etk.hu) 